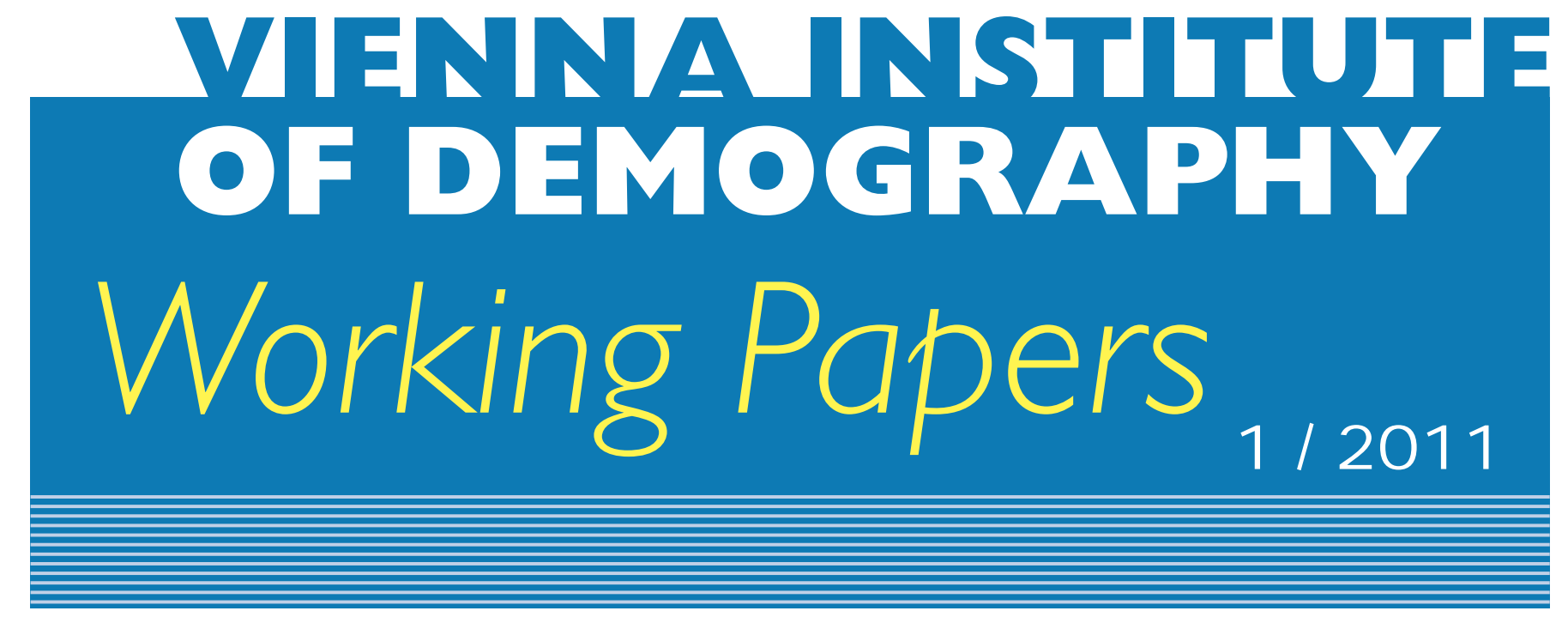

Isabella Buber, Caroline Berghammer, and Alexia Prskawetz

\title{
Doing Science, Forgoing Childbearing? Evidence from a Sample of Female Scientists in Austria
}

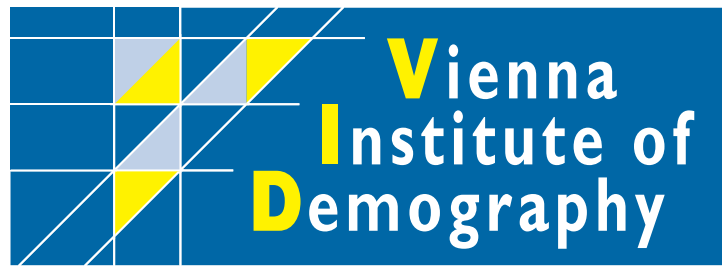

Vienna Institute of Demography Austrian Academy of Sciences

Wohllebengasse 12-14

A-I040 Vienna $\cdot$ Austria

E-Mail:vid@oeaw.ac.at

Website: www.oeaw.ac.at/vid 


\begin{abstract}
Academic women in Austria and Germany have extraordinarily high final levels of childlessness of $45-60 \%$, as documented by prior research. This study investigates how female scientists' fertility behaviour relates to their childbearing ideals and intentions in Austria. It analyses whether high childlessness and low numbers of children are intended or not. By looking additionally at employment conditions and partnership status, this study points to possible obstacles hindering couples to realise their childbearing desires. Furthermore, it shows how female scientists combine their academic career and childcare. The analysis is based on a sample of female scientists who had applied for a grant at the Austrian Academy of Sciences $(n=196)$. It comprises women aged 25-45 who work in different scientific fields in Austria. Female scientists aged 40-45 have 0.9 children on average and $44 \%$ remain childless. However, these levels are far from the number of offspring that young scientists under the age of 35 intend to have. They perceive on average two as their ideal and intended number; only around $10 \%$ want to stay childless. Several obstacles which impede childbearing were identified, e.g. the strong work commitment of the female scientists, the need to be geographically mobile and the high prevalence of living apart together relationships. As for the combination of work and family, female scientists return back to work quickly after they have a child. Most do not regard the family as the main caregiver but perceive a division of tasks between the family and the public as preferable.
\end{abstract}

\title{
Keywords
}

Female scientists, fertility, intentions, Austria, GGS

\section{Authors}

Isabella Buber is Research Scientist at the Vienna Institute of Demography of the Austrian Academy of Sciences. Email: isabella.buber@oeaw.ac.at

Caroline Berghammer is Research Scientist at the Vienna Institute of Demography of the Austrian Academy of Sciences. Email: caroline.berghammer@oeaw.ac.at

Alexia Prskawetz is Professor at the Institute of Mathematical Methods in Economic at the Vienna University of Technology and deputy director of the Vienna Institute of Demography of the Austrian Academy of Sciences. Email: afp@econ.tuwien.ac.at

\section{Acknowledgements}

We would like to thank Wolfgang Lutz for helpful comments as well as Barbara Haberl and Birgit Distler from the Office for Fellowships and Awards of the Austrian Academy of Sciences and Petra Schmutz for their valuable help and support. Data collection among female scientists was financed by the Austrian Academy of Sciences. The Austrian GGS was conducted by Statistics Austria with the financial support of the Federal Ministry of Economy, Family and Youth, the Federal Ministry of Science and Research and the Federal Ministry of Labour, Social Affairs and Consumer Protection. We are grateful to Heike Barakat for language editing. 


\title{
Doing Science, Forgoing Childbearing? Evidence from a Sample of Female Scientists in Austria
}

\author{
Isabella Buber, Caroline Berghammer, Alexia Prskawetz
}

\section{Introduction}

Recent studies show that childlessness among female scientists is very pronounced. Research from Germany and Austria concludes that $45-60 \%$ of female researchers past their fertile period (cohorts around 1950-60) and female professors remain childless; for their male counterparts these numbers turn out to be only half as high (Buchholz 2004; Fieder et al. 2005; Auferkorte-Michaelis et al. 2006; Metz-Göckel 2009; Krimmer et al. n.d.). Among the overall female population childlessness adds up to $14-17 \%$ for the birth cohorts 1949-63 in Germany (Statistisches Bundesamt 2009) and about 13-16\% among similar birth cohorts in Austria (Prskawetz et al. 2008). These figures document a large gap in the fertility behaviour of female and male scientists as well as between female scientists and the overall female population.

Former studies on the fertility of female scientists either pointed to obstacles in combining science and having children - such as long working hours, geographic mobility or fixed-term contracts - (e.g. van Anders 2004; Comer and Stites-Doe 2006), assessed the effect of parenthood on work performance (e.g. Romanin and Over 1993; Lind 2008) or formulated policy suggestions (e.g. Armenti 2004; Ward and Wolf-Wendel 2004). Our study contributes to this line of research by addressing the following questions:

How can the employment and partnership situation of female scientists be characterised? These two aspects are among the major factors forming the context in which childbearing decisions are taken.

How do childbearing ideals and intentions compare to the realised number of children? Findings to date offer scarce evidence as to whether high childlessness levels are intended, arguably rooted in the work-orientation of female scientists or an involuntary outcome which is due to factors impeding the realisation of the desired number of children.

How do female scientists organise their lives with respect to combining research and raising children? The age of the child when returning to work, the working hours and the partner's involvement as well as attitudes towards external childcare are important aspects for analysing the reconciliation of family and work.

From a more historical point of view, Wasserman (2002) addressed the role of women in science and interviewed women elected to the U.S. National Academy of Sciences between 1957 and 1996. She portrayed these women born between 1898 and 1956 who managed to achieve outstanding careers as scientists and explicitly addressed the combination of family and science. The majority of these women had children, they forged individual solutions and managed to work overload in a variety of different ways. It turned out that "the dominant theme that persuaded interviews with women of all ages and all disciplines" was the dilemma women encounter in balancing career and family responsibilities (Wasserman 2002: 189). 
Ingrisch (1993) studied the life of the first female professors at the University of Vienna by conducting narrative interviews with them. ${ }^{1}$ Two patterns emerged for the combination of family and scientific work. Some women only dedicated themselves to their intellectual work, considered the institute as their home and rejected everything that had to do with a partnership. Another group of women combined scientific work and family in the style of a career woman with children. Such arrangements were conditional on their husbands' agreement and implied their sustained responsibility for a "happy, satisfying and presentable family life" (Ingrisch 1993: 145).

Austria is among the countries with a negative educational gradient of fertility: women with basic education display the lowest childlessness, the highest progression rate to third child and a completed fertility close to replacement level whereas university education is coupled with high childlessness and a low level of completed fertility for women (Prskawetz et al. 2008). In addition, large fertility differentials by educational field and profession prevail among women with tertiary education (Spielauer 2005; Neyer 2009). For instance, teachers and women in health occupations record lower childlessness and higher fertility. Although varying across different disciplines and work environments, the scientific profession is characterised by high geographic mobility, temporary contracts, continuous investment in human capital, networking at the national and the international level and recurrent deadlines which often require long working hours. Kemkes-Grottenthaler describes a scientific career as a path of "endless qualification, publication pressure and time-consuming research" (2003: 214). Such job characteristics may hamper straightforward compatibility between childrearing and pursuing a scientific career.

Whereas studies on female academics in the United States are quite numerous, the situation of their European peers was less often investigated. But with regard to Europe the awareness of the scientific community is now rising, partly driven by the underrepresentation of women in science. For instance, during the last years the German Federal Ministry of Education and Research provided funds under the project title "Frauen an die Spitze (Women to the top)" which aims at exploring the circumstances of male and female scientists in Germany and at studying the balance of parenthood and an academic career at German universities.

To date, evidence on fertility and work-family-reconciliation of female scientists in Austria is scarce (for exceptions see: Buchinger et al. 2002; Appelt 2004; Fieder et al. 2005; Buchmayr and Neissl 2006). The Austrian Academy of Sciences initiated and financed a micro-level survey among women with scientific aspirations in Austria in order to explore their personal as well as their employment situation and to capture their specific needs, especially with regard to combining both. The study at hand is based on this non-random sample of 196 female scientists in the age bracket 25-45. In order to reach those with high career aspirations women who had applied for a scholarship at the Austrian Academy of Sciences were sampled. The data were collected in 2009 in face-to-face interviews. Focusing on childbearing and partnership, the questionnaire contains a large number of items on intended and realised fertility, ideal family size, attitudes towards childbearing, childcare arrangements, partnership history, gender relations etc.

Differently from most past research we do not compare female scientists to their male colleagues, but contrast them with two other groups of non-scientists: women who also completed tertiary education and women with less than tertiary education. Estimates for these

\footnotetext{
${ }^{1}$ As late as in 1956 the first woman, physicist Berta Karlik, was appointed as full professor.
} 
two categories are based on the nationally representative data of the Austrian Generations and Gender Survey ( $\mathrm{n}=3,001$ women), which was fielded in the same period using the same questionnaire.

\section{Literature review}

\subsection{Characteristics of scientific work}

For women higher education often pairs with low fertility (Spielauer 2005; Dorbritz 2008; Prskawetz et al. 2008). The well-known neo-classical theory ascribes this association to the fact that women with a higher educational degree face higher opportunity costs of childrearing: Compared to their lower educated peers, they attain on average higher monetary returns from paid labour and therefore incur higher opportunity costs in terms of foregone wages if they stay out of the labour force (Becker 1993). Since females are in general the main caregivers, the incentive to have a large number of children might therefore be lower among highly educated. A sociological theory complements this explanation by arguing that some women just have stronger lifestyle preferences for work, others for family life. Highly educated lean more towards the first category (Hakim 2003). Female scientists all hold a university degree, many of them even earned a PhD. As a consequence their childbearing patterns should be distinct from that of lower educated women solely because of their educational attainment. But moreover, job type characteristics come into play: scientific work has some features that obstruct easy compatibility with childrearing. As Ward and WolfWendel state pointedly: "Academic work is consuming by its nature." (2004: 248) However, we do not claim that scientific work is more difficult to reconcile with a family than any other specific occupation, but we draw attention to its special characteristics by reviewing past research.

First, the time structure of scientific work differs from that of most other occupations. Working hours are generally high and it is not unusual that they exceed contracted ones. Particularly in times of high demand work spills into free time blurring the boundaries between the two (Buchinger et al. 2004; Beaufaÿs 2006; Buchinger 2006). This has to do with the nature of academic work: "There are always articles to read, papers to grade, syllabi to update, and proposals to write. Work never ends in terms of quantity" (Ward and WolfWendel 2004: 245). On the other hand, the work schedule is generally flexible as is the work place which facilitates combining work and family duties (Macha 2005; Buchinger 2006).

In science, being geographically mobile is necessary to undertake research stays, to take part in conferences, workshops as well as guest lectures and to obtain extended education. Job mobility is high in the scientific field and may entail the opportunity or need to move to another place. Such mobility is frequently not easy to reconcile with a family (Ackers and Gill 2008).

Another trait of scientific positions is that contracts are often temporary implying uncertainty with regard to future plans (Metz-Göckel 2009). In an optimal case, scientific work is carried out without interruption; the reasons being that up-to-date knowledge is essential, the publication record ideally does not show any gaps (Ward and Wolf-Wendel 2004; Buchinger 2006) and the model of the university career is continuous - more so in the US where one follows a tenure track (Ward and Wolf-Wendel 2004). These requirements are at odds with breaks or reduction of working hours after the birth of a child. McDowell (1982) ascertains 
that career interruptions are most detrimental in disciplines where knowledge renews the fastest. He infers that a break is worst in physics and chemistry and least consequential in history and English. Biology, sociology and psychology lie in the middle.

Another fact which was identified as problematic for combining scientific work and parenthood is the "myth of a scientist" (Buchinger et al. 2004; Beaufaÿs 2006; Wyer et al. 2010). It regards the scientist as a person who fully devotes his or her life to science and moves freely without being constrained by social conditions or relations (Beaufaÿs 2006). Having children, however, imposes strings on time, energy and geographical mobility, at least for the primary caregiver who typically is the woman. Therefore, women with children are stereotyped in a negative way as being less serious about their career (Long and Fox 1995; Armenti 2004). But scholars argue that even before they have children female researchers are confronted with a deficit of trust, because they are potential mothers (Lind 2007).

Finally, the opportunity costs we mentioned above - foregone earnings - do apply to scientific work. Being employed as a scientist entails financial independence and, moreover, is frequently rated as satisfactory since it involves challenges, autonomy and flexibility (Ward and Wolf-Wendel 2004; Macha 2005).

These traits give a stylised picture of scientific work. We certainly do not argue that they characterise all scientific positions or that they impose constraints on the reconciliation between work and family in all cases. In fact, Comer and Stites-Doe (2006) identified mediating factors which influence whether balancing is successful or not. Regarding the job the stage in career, the type of institution, the work-family culture at the workplace including the availability of on-site childcare have to be mentioned. Regarding the family the partner's engagement in childcare, the partner's encouragement of academic role and the age of children matter.

\subsection{Combination of work and family life}

The potential problems just discussed characterise academic work as such and are experienced by scientists who actually bear the prime responsibility of bringing up their offspring. As confirmed by many studies these are usually the female scientists rather than their male partners (e.g. Leemann 2002; Buchholz 2004; Lind 2008; Krimmer et al. n.d.). They therefore take more often career breaks and work more frequently part time (Romanin and Over 1993; Buchholz 2004). The literature is full of studies which substantiate negative consequences of parenthood on the women's scientific career (e.g. Allmendinger et al. 1999; Buchholz 2004; Lind 2008). ${ }^{2}$ They are much less marked for male scientists with children. For instance, female researchers state - more often than males - that having a family limits their time for research, their possibility to get a job elsewhere, restricts the opportunity of attending conferences etc. (Romanin and Over 1993). They report more often than their male counterparts to have changed their career plans due to their family planning (O'Laughlin and Bischoff 2005: 90). Keeping social networks was found to be more problematic when having a child (Leemann 2002: 181; Lind 2008: 21). Women with a child under the age of six were less likely to obtain a tenure-track position than their childless colleagues (Wolfinger et al. 2008). However, studies disagree as to whether publication productivity and having children

\footnotetext{
${ }^{2}$ Nevertheless also male professors report problems when combining their work with fatherhood (Reuter et al. 2008).
} 
are negatively (Hargens et al. 1978; McDowell 1982; Stack 2004), positively (Fox and Faver 1985; Kyvik 1990) or not at all related (Hamovitch and Morgenstern 1977) and they obtain mixed results (Fox 2005). Research also claims that having children alters women's priorities, decreases their expectations regarding their work and renders them to develop more efficient work styles (Ward and Wolf-Wendel 2004, 2006; Lind 2008). While studies argue on the one hand that handling childcare and work triggers stress (Ward and Wolf-Wendel 2004; O'Laughlin and Bischoff 2005), they show on the other hand that stress in the work domain may be buffered by the family domain and vice versa (Macha 2005; Ward and Wolf-Wendel 2006). They generally allude to the benefits of multiple roles: having both a family and a career is satisfying (Ward and Wolf-Wendel 2004).

Even before experiencing any incompatibility between family and job responsibilities themselves, childless female scientists anticipate it (Kemkes-Grottenthaler 2003; van Anders 2004; Lind 2008). Therefore, they are very careful in fitting their childbearing plans into their career aspirations (van Anders 2004; Wolf-Wendel and Ward2004) and show a high willingness to postpone motherhood (Kemkes-Grottenthaler 2003). While from a life-course perspective a scientist is probably most pressured during the years of establishing oneself within the scientific community and working towards tenure, the biological clock is ticking in parallel.

That science holds several obstacles with respect to combining it with parenthood, is regarded to be one of the reasons why women are underrepresented in this occupation (e.g. Long and Fox 1995; van Anders 2004). ${ }^{3}$ The share of females declines with increasing rank, which was termed the "leaky pipeline". In Austria females made up close to $60 \%$ of students who finished their first studies at Austrian universities in 2009, they constituted $40 \%$ among assistants and 20\% among professors in the same year (BMWF 2010). ${ }^{4}$ The share of females among researchers amounted to 30\% in EU-27 in 2006. In Austria it lies with 25\% below this share. However, between 2002 and 2006 the rate of increase was higher among women than men in the EU-27 (6.3 versus 3.7\%) as well as in Austria (11.2 versus 4.3\%; EC 2009). It is not least for the reason that women are becoming increasingly present among scientists that obstacles for realising their childbearing intentions should be identified and possibly removed. ${ }^{5}$

\subsection{Fertility intentions and behaviour of female scientists}

Dropping out of science for reasons of experiencing or anticipating difficulties with raising offspring is one strategy to avoid the conflict. Another one seems to be to forgo children. Subsequently, we look at evidence on female scientists' fertility levels in Germany

\footnotetext{
${ }^{3}$ Other factors as summarised by Kreetz (2004) and Lind (2007) are: students face gender-specific cultures of confirmation which render women to feel less encouraged; informal recruitment promotes hiring people of the same sex, i.e. males; women are more defensive in profiling, less prepared for competition and underestimate their skills; female scientists experience lower encouragement, support and less integration in the scientific community.

${ }^{4}$ Certainly, the gender composition of students differed when today's professors completed their studies. However, Lind (2007) demonstrated in a cohort analysis that about $20 \%$ of female professors were appointed from 2003-05 in Germany, while 40\% of students who finished their studies in the relevant time before (18 years) were women.

${ }_{5}^{5}$ An empirical study among scientists at German universities found that $46 \%$ suggested that balancing academic work and family responsibilities has become easier over time, while only $18 \%$ think the opposite (Lind 2008).
} 
and Austria. At this point, we come back to our initial considerations and also refer to research on fertility behaviour of women with different educational levels.

While a number of studies investigate realised fertility, very little research deals with fertility intentions of female scientists. Kemkes-Grottenthaler (2003) and Lind (2008) constitute notable exceptions. Both find that childlessness intentions are far below observed levels. 14\% of childless female faculty members at the university of Mainz stated decidedly that they do not want any children and 11\% were uncertain about it (Kemkes-Grottenthaler 2003). 17\% of the childless scientists at 19 German universities surely wish to remain childless and $17 \%$ are unsure (Lind 2008). Surprisingly high are also their ideal numbers of children: most faculty members indicated 2-3 (Kemkes-Grottenthaler 2003) and 2 as the modal number, respectively (Lind 2008). In both studies, however, especially women considered the chance of realising these numbers as very low. Nevertheless, these studies do not support a perception of widespread voluntary childlessness.

But as a matter of fact, $45-60 \%$ of female scientists and professors end up without any children. $60 \%$ of female scientists aged $43-53$ at the universities of North-Rhine Westphalia are recorded as being childless (Auferkorte-Michaelis et al. 2006). A study on female professors in eight of the sixteen German federal states finds a similar share of $62 \%$ (MetzGöckel 2009), while another study of female professors in six disciplines reports 50\% childlessness (Krimmer et al. n.d.); unfortunately both results were not disaggregated by age. An Austrian study indicates that $43 \%$ of female professors in the age-group 41-50 remain childless (Buchholz 2004). About 45\% of females aged 40-54 in the highest status category at the University of Vienna stay childless (Fieder et al. 2005). The very high childlessness produces very low mean numbers of children (Fieder et al. 2005; Krimmer et al. n. d.). A comparative analysis revealed that such elevated levels of childlessness as in Germany and Austria are exceptional. Among female professors, childlessness amounts to around 25\% in Poland, close to $20 \%$ in Sweden and to about 10\% in France and Spain (Lind and Banavas n. d.).

Germany and Austria are marked by moderately low fertility and high general levels of childlessness (Frejka 2008) with great educational differences in childbearing behaviour. In Germany, the mean number of children is 1.5 for women with tertiary and higher secondary education and 1.7-1.8 for those with lower secondary education for cohorts born between 1949-63 (own calculations based on Statistisches Bundesamt 2009). 25-26\% of women with tertiary or higher secondary education remain childless, while this compares to $14 \%$ in the groups with lower secondary education (Statistisches Bundesamt 2009).

In Austria, tertiary and higher secondary educated women have 1.4-1.5 children on average, those with lower secondary come to 1.7 and those with basic stand at 2 (Prskawetz et al. 2008). As in Germany, childlessness increases with the level of education: it is $30 \%$ among tertiary educated, $22 \%$ among women with higher secondary education and $14 \%$ among women who have at most lower secondary or basic education in the cohorts born between 1955-60 (Prskawetz et al. 2008). Neyer and Hoem (2008) depicted that not only level but also the field of education matters for childlessness in Austria. Women educated as social scientists show almost $40 \%$ childlessness, those trained in the humanities about one third and natural scientists around one quarter.

The literature supports the view that the lower family sizes of highly educated women are due to problems preventing the realisation of their fertility desires rather than a consequence of 
low fertility intentions (for an international overview see Sobotka 2009). Heiland et al. (2005) show for West Germany that the desired mean number of children ranges between 2.2 and 2.3 for all educational levels from lower secondary education onwards for women aged 36-45. Since the highly educated are least likely to achieve these levels, the gap between desired and realised fertility is highest for them. Similarly, Sobotka (2009) substantiates for Austria that the mean desired number of children is about 1.7-1.8 children for all educational levels for women aged 26-30. In line with other studies, highly educated Austrian women are more likely to revise their childbearing intentions downwards than the lower educated.

\section{Data}

In 2008/09, Austria launched the first wave of the 'Generations and Gender Survey (GGS)' which focuses on family dynamics. The Austrian GGS is part of a larger program of representative surveys in 17 countries coordinated by the United Nations Economic Commission for Europe. In Austria, in total 3,001 women and 1,999 men aged 18 to 45 years were interviewed. In nationally representative samples, the absolute number of tertiary educated respondents is usually small disabling in-depth analyses of this group. Moreover, the identification of scientists is difficult since predetermined employment codes do not flag all cases. In order to still be able to gain insights in the family formation process and the combination of work and motherhood of academic women, an additional sample of female scientists was surveyed, financed by the Austrian Academy of Sciences. This institution supports young researchers with different grant schemes and has a special interest in improving the conditions of ambitious scientists.

However, since it is not feasible to draw a random sample of all female scientists in Austria, we used the addresses that were provided by the administration of grants of the Austrian Academy of Sciences to contact women up to the age of 45 years who had applied for a grant there. They therefore must have had scientific aspirations at some point. We can suppose that this population contains highly qualified individuals who are particularly motivated to fulfil their ambitions. In a first round, letters were sent out, followed by emails in case of no response. Altogether 1,561 women were contacted. Due to invalid postal as well as emailaddresses, 433 messages were undeliverable, reducing the number of contacted women to 1,138 . Nevertheless, it is likely that our request for participation did not reach some of these women either. In total, 247 women aged 25-45 were interviewed in Computer Assisted Personal Interviews, corresponding to a response rate of $22 \%$ (Buber 2010a). Since it is not known how many women could definitely be reached, our response rate can be regarded as minimum. Van Anders (2004) indicated similar problems for calculating the response rate for an online questionnaire which was sent out to graduate students by email.

Out of these 247 women, we base our analyses on the 196 who work in science and research. They are mostly employed at universities $(80 \%)$, but also at non-university research institutes and in research and development departments of private companies $(20 \%)$. The vast majority of university based interviewees $(87 \%)$ belonged to the non-professional teaching staff, the so-called 'Mittelbau' comprising persons at the beginning of their scientific career or at an intermediate level like assistants or senior assistants. The interviewed scientists belonged to different scientific fields, like humanities and arts, social sciences, economics and law, natural sciences and others. Both, successful and non successful applicants for doctoral and postdoctoral grants of the Austrian Academy of Sciences are represented in our sample. $20 \%$ held a grant of the Austrian Academy of Sciences at the time of the interview, further $31 \%$ were 
former scholarship holders. For the remaining 49\% the application for a grant at the Austrian Academy of Sciences was not successful. Nevertheless, they might have been successful in receiving other grants to be able to carry out scientific work, e.g. from the Austrian Science Fund (FWF). Unfortunately, this information is not coded in our data.

Response rates differed whether an applicant was successful or not. Whereas $51 \%$ of all current and 38\% of former scholarship holders agreed to be interviewed, the response rate of not successful applicants amounts to only $18 \%$. On the one hand, this may have to do with differences in their personal willingness, on the other hand on the up-to-dateness of the contact details the administration of grants holds. Moreover, the longer the application dates back, the lower the response rate ${ }^{6}$. This pattern is reflected in the age distribution of our sample: Nearly two thirds of the interviewed scientists were under the age of 35 and only one third between 35 and 45 years. Therefore our sample of female scientists includes many young researchers who are at the beginning of their scientific career.

We acknowledge that our sample is very specific and that findings are not necessarily generalisable to female scientists in Austria. Nevertheless, our results allow valuable insights into partnership arrangements and working environment, childbearing plans and behaviour as well as reconciliation of work and family of female scientists of diverse scientific disciplines in Austria. Many international studies on scientists are based on similarly non-representative and small samples (e.g. Romanin and Over 1993; van Anders 2004; O'Laughlin and Bischoff 2005; Kemkes-Grottenthaler 2003). They also sometimes report low response rates of $18 \%$ (van Anders 2004), 22\% (Lind 2008) or 37\% (Kemkes-Grottenthaler 2003), respectively.

Collecting data on female scientists as an additional sample to the GGS is advantageous in two respects: first, the rich information contained in the GGS questionnaire allows presenting a comprehensive picture of our interviewed female scientists. We dispose of data on family background, partnership histories, fertility histories, fertility intentions and ideals, own and partner's employment, financial situation, distribution of household and childrearing duties as well as attitudes towards marriage, family and gender relations. Second, we are able to compare our selected sample with highly educated women not working in a scientific environment $(n=377)$ as well as with lower educated women $(n=2,076)$ in the same age bracket included in the GGS.

In addition to the detailed GGS questionnaire, we included questions specific to work in science like current position and working branch, duration of work contracts and job security, stays abroad, perceptions on pursuing a scientific career and being a mother, as well as requests regarding compatibility between family and work to policy makers, universities and other institutions who employ scientists.

Besides the bias towards successful and current applicants, we assume a further bias towards family oriented women. The GGS focuses explicitly on dynamics of families and family relationships, and it is known for the sample of the general Austrian population that the childless were underrepresented. This was corrected in the weights, which we use throughout our analyses for highly educated non-scientists and lower educated women (Buber 2010b). Since the cohort-specific parity distribution of scientists is not known, we are not able to correct for it.

\footnotetext{
${ }^{6}$ For further information on the sample and the response rate see Buber (2010a).
} 


\section{Results}

\subsection{Living conditions: education, employment and partnership}

As a first step, we briefly sketch the living conditions of female scientists and contrast them with those of tertiary and lower educated non-scientists. Decisions in the family domain are closely interlinked with education, employment characteristics and partnership status. Table 1 provides rich information on these fields, which we discuss in this section. Since the interviewed scientists exhibit a younger age structure than their peers, we disaggregate all variables by age to enable a valid comparison.

Regarding education, the share holding a $\mathrm{PhD}$ is more than fourfold among female scientists than among their tertiary educated counterparts (58\% versus $13 \%)$. A $\mathrm{PhD}$ is commonly regarded as a prerequisite for a scientific career. As can be expected, a strong correlation between age and doctoral degree exists: more than $80 \%$ of women aged $35-45$ years had a $\mathrm{PhD}$ as opposed to $19 \%$ among women aged 25-29 years. The fact that four out of ten interviewed young women under 30 were receiving a pre-doctoral grant indicates that they were aiming at a $\mathrm{PhD}$.

Nine out of ten interviewed scientists were employed at the time of the interview, compared to eight out of ten women in the two other groups, which corresponds to the female labour force participation rate in the years 2008 and 2009 of women aged 25-44 years (Statistik Austria 2010a). The scientists' strong attachment to work is also reflected in the high proportion of full-time employees (scientists: 73\%; tertiary educated: $62 \%$; secondary and lower educated: $51 \%$ ). Particularly noteworthy is the high proportion of female scientists who work 45 hours and more each week amounting to $41 \%$ compared to $23 \%$ among tertiary educated and $11 \%$ among secondary and lower educated non-scientists. A larger number of working hours was found to be positively associated with an increase in work-family conflict because time devoted to one role may lead to time constraints in other roles, e.g. as a partner or mother (Greenhaus and Beutell 1985).

Differently from many other occupations, scientific work is less bounded to a specific workplace, which is why about one quarter of scientists (partly) work at home (tertiary educated: 14\%; secondary and lower educated: 10\%). On the one hand, such a work arrangement may support reconciling work and motherhood and be particularly beneficial when having young children. On the other hand, keeping the boundary between work and private sphere may get challenging and recreation may become difficult.

The great majority of scientific employees holds temporary contracts $(75 \%)$, i.e. nonpermanent contracts which expire at a predetermined point in time. As expected, the proportion of scientists with temporary contracts decreases strongly with age. Among female employees with tertiary education as well as with secondary and lower education, temporary contracts are markedly less prevalent $(20 \%$ and $9 \%)$. Temporary contracts imply uncertainty and render planning over a longer period of time difficult, also with respect to the family domain. For Germany, Auferkorte-Michaelis et al. (2005) argue that the high levels of childlessness among young researchers reflect the unstable employment situation, including temporary contracts and reduction of staff.

Female scientists appear to be as satisfied with their job as other tertiary educated women, while secondary and lower educated indicate slightly higher satisfaction. Among scientists, 
the job satisfaction correlates with the type of contract with women holding a permanent contract being more satisfied than those with temporary contracts. This holds for all age groups, but especially for women aged 35-39 years. We might speculate that the uncertainty related to non-permanent contracts is a burden especially for women who could not achieve stable positions by their late $30 \mathrm{~s}$. The negative association between job-satisfaction and temporary contracts is not observed among tertiary or secondary and lower educated women.

Next to these general aspects, specific features characterise scientific work. Among them is the urge to go abroad for scientific exchange, conferences and workshops as well as extended education. The interviewed scientists are rather active in this respect. Two thirds of the women aged 35-45 had stayed abroad for at least three months for work-related reasons and one third of the women aged 40-45 had lived abroad for two years and more. Professors and habilitated women exhibited the highest mobility. What kind of consequences for their partnership and family planning did the women experience? Half of the women reported (major or minor) negative consequences for their partnership, particularly related to longer stays abroad. However, $20 \%$ indicated very positive consequences. The same individuals also reported (very) positive consequences for their family planning. In general, negative consequences of stays abroad were less frequently mentioned in relation to family planning $(20 \%)$, more often so for longer stays abroad. Concerning participation in conferences, the scientists were rather mobile as well. For instance, half of them estimated to have partaken at ten or more conferences within the last three years.

How do female scientists and their partners fare with regard to their economic situation? While entering the labour market female scientists receive a lower income than their tertiary educated peers in other occupations but they achieve a steeper increase. One half of female scientists aged 35-45 reports a net salary of 2,000€ and more, whereas the respective share is $37 \%$ among tertiary educated non-scientists. A crude estimation for our interviewed scientists was around 1,900€ for the age group 35-39 and 2,500€ for the age group 40-45 and about $1,700 €$ and $1,900 €$ for women with tertiary education, respectively ${ }^{7}$.

The different income levels reflect in part different extends of working hours. We also have to bear in mind that labour force participation and income depend on the number of children and the age of the youngest child. For estimating the financial situation of a family partner's income and transfer payments like child allowances are crucial. Therefore, the more general indicator of how easily a household is able to make ends meet is depicted (Litwin and Sapir 2009). Scientists and women with tertiary education evaluate their financial situation similarly whereas lower educated ones more often report financial constraints. About $15 \%$ of scientists state difficulties to make ends meet, whereas roughly $60 \%$ get along with their household income (very) easily.

\footnotetext{
${ }^{7}$ Income was coded in categories, the highest category being an open interval $(5,000 €$ and more). We calculated the mean income by taking the mean of the upper and lower bound as the representative for each category. For the highest income category which was reported by only four women, we have chosen the lower limit as representative for calculating the mean income.
} 


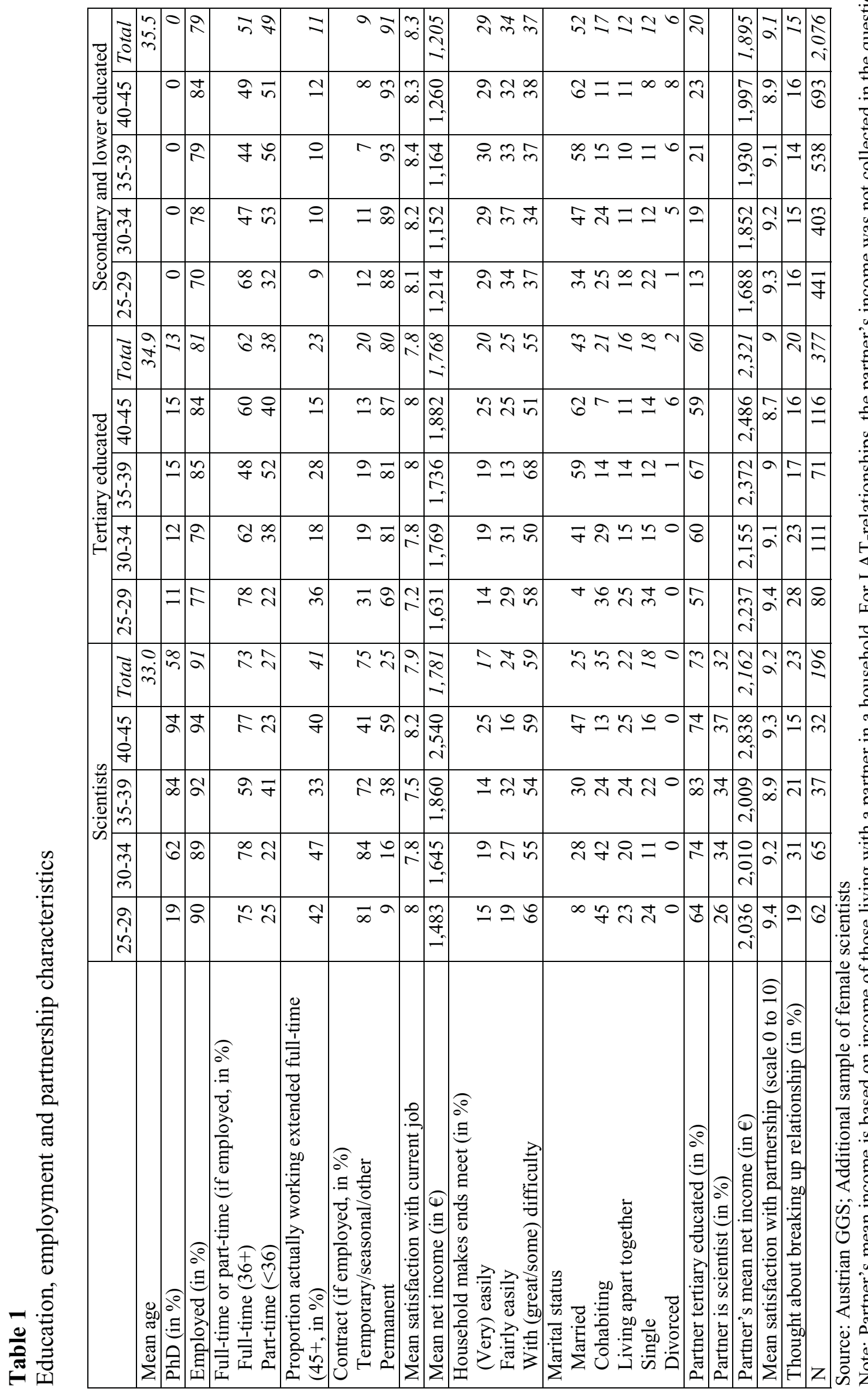


Regarding partnership form, female scientists cohabit and live apart together (LAT) more often than their peers, who rather tend to get married. The largest relative difference is discernible in the age group 35-39 where only about half as many scientists are married as in the other two groups. Whereas the proportion of scientists living apart together is stable at 20$25 \%$ across age groups, this living arrangement decreased progressively among their nonscientists counterparts aged 30 and over. Across all educational groups, for one out of two women living apart together was not voluntarily chosen but a consequence of external circumstances. Housing conditions (like a small apartment) were often mentioned as a reason for not sharing a common household by women with secondary and lower education, but higher educated women referred more often to work-related causes. But even though female scientists differ in their partnership arrangements, they did not have a partner more seldom.

How do partnership arrangements of female scientists potentially affect childbearing? Living with a partner is crucial for the formation of a family and in this regard, female scientists face less favourable circumstances than their peers. In Austria out-of-wedlock births have a long tradition (Haslinger 1982; Mitterauer 1985) and are widely accepted. During the last years half of all first births were nonmarital, mostly born to cohabiting mothers (Statistik Austria 2010b). Nonetheless, marriage continues to be interpreted as an indicator for a high commitment to the partner. It is frequently regarded as a more suitable surrounding for having and raising children than cohabitation.

Female scientists more frequently (74\%) live in educationally homogameous relationships with a tertiary educated partner than their highly educated peers $(60 \%)$ and lower educated women $(20 \%)$. In roughly one third of the cases their partner is also employed as a scientist. Despite these differences in the proportion of highly educated partners, we find that the mean income of the female scientists' partners was slightly lower than that of partners of tertiary educated non-scientists. ${ }^{8}$

Concerning partnership quality, the interviewed scientists are rather satisfied with their partnerships. On a scale from zero to ten, the mean score was 9.2, similar to women in the two reference groups. About one in five women had thought about ending their partnership during the last year among the two groups of highly educated women. The respective share is a bit lower among women with secondary and lower education. Certainly, considering a separation from the partner is not a favourable situation for family formation.

\subsection{Fertility ideals, intentions and behaviour}

Initially, we posed the question whether the very low fertility of female scientists is due to their lower family size ideals and intentions or whether it is an outcome of obstacles in combining their work and raising offspring. In order to shed light on this question we first analyse fertility ideals and intentions followed by an analysis of the realization. Regrettably, we do not dispose of panel data which tracks the same individuals over a period of time, and our inferences are therefore based on results for different age groups from different cohorts.

\footnotetext{
${ }^{8}$ Partner's mean income is based on income of those living with a partner in a household. For LATrelationships, the partner's income was not collected in the questionnaire. The partner's mean income was coded in categories, means were calculated in the same way as the respondent's mean net income as described above.
} 
Interestingly, female scientists perceive on average 2.0 children as ideal, which is close to the perception of the other two groups of women (Table 2a). ${ }^{9}$ The ideal number is identical for tertiary educated non-scientists and lies at 2.2 for secondary and lower educated women. For scientists, the average mean number decreases with age: it lies between 2.0 and 2.2 under the age of 40 , and declines to 1.8 when they are 40-45. We find no systematic differences across different disciplines. These first results reveal that the ideal family size is very similar across educational levels, while realised fertility differs substantively as will be documented below.

At least half of the women in all three educational categories regard two children as their personal ideal (Table 2b). A surprisingly large jump is discernible in the ideal of staying childless for female scientists aged 35 and older. One child is a personal ideal for a rather small group of female scientists, but becomes increasingly so for tertiary educated nonscientists as they age. We may speculate that female scientists opt for staying childless once they realise they cannot fulfil their intentions, whereas tertiary educated non-scientists rather come to perceive one child as ideal. Since we do not dispose with information on changes in the ideal over the life course of individuals, we cannot substantiate this supposition empirically. A substantial proportion of women (20-30\%) perceives three or more children as their personal ideal, most often among the secondary and lower educated.

\section{Table 2a}

Personal ideal number of children, means

\begin{tabular}{|l|c|c|c|c|c|}
\hline & $25-29$ & $30-34$ & $35-39$ & $40-45$ & Total \\
\hline Scientists & 2.0 & 2.2 & 2.1 & 1.8 & 2.0 \\
\hline Tertiary educated & 2.1 & 2.0 & 1.9 & 2.1 & 2.0 \\
\hline Secondary and lower educated & 2.1 & 2.2 & 2.2 & 2.3 & 2.2 \\
\hline
\end{tabular}

Table 2b

Distribution of personal ideal number of children (in \%)

\begin{tabular}{|l|l|c|c|c|c|c|}
\hline & & 0 & 1 & 2 & $3+$ & Total \\
\hline \multirow{3}{*}{ Scientists } & $25-34$ & 4 & 8 & 67 & 21 & 100 \\
\cline { 2 - 7 } & $35-45$ & 13 & 9 & 51 & 26 & 100 \\
\cline { 2 - 7 } & Total & 7 & 8 & 62 & 23 & 100 \\
\hline \multirow{4}{*}{ Tertiary educated } & $25-34$ & 3 & 12 & 65 & 20 & 100 \\
\cline { 2 - 7 } & $35-45$ & 5 & 18 & 55 & 22 & 100 \\
\cline { 2 - 7 } & Total & 4 & 15 & 60 & 21 & 100 \\
\hline \multirow{3}{*}{ Secondary and lower educated } & $25-34$ & 2 & 13 & 60 & 26 & 100 \\
\cline { 2 - 7 } & $35-45$ & 4 & 11 & 53 & 31 & 100 \\
\cline { 2 - 7 } & Total & 4 & 12 & 56 & 29 & 100 \\
\hline
\end{tabular}

Note: The table does not include women who refused the question or answered with "don't know" (in total less than $1 \%$ ).

Besides the ideal number of children, the GGS includes several items on fertility intentions allowing us to calculate the total intended number of children by adding the current number of

\footnotetext{
${ }^{9}$ The wording of the question is: "And for you personally, what is the ideal number of children you would like to have or you would have liked to have?" The reader has to keep in mind that the question on ideal family size was positioned at the end of the questionnaire, after detailed questions on realized children and childbearing intentions. Possibly, some respondents might have given a different answer if they had been asked about their family ideals without any previous detailed questions on fertility (Mathews and Sear 2010).
} 
children and the number of (further) intended children. A disaggregation by age and educational level reveals that fertility intentions are similarly high across groups at younger ages (Table 3). This observation is in line with a number of past studies (e.g. Heiland et al. 2005; Liefbroer 2009; Sobotka 2009). While childbearing intentions are quite stable over age for lower educated women, they decrease more among the highly educated, tying in with previous findings (e.g. Quesnel-Vallée and Morgan 2003; Liefbroer 2009). Fertility intentions are at about the same level for women up to the age of 34 years. But in the age groups 35-39 and 40-45 intentions decrease substantially for women with tertiary education and even more for female scientists. People's intentions are changing as a result of their experiences. Highly educated women are more likely to follow a career in a higher status job, hence, their costs of childbearing are higher and they are more prone to adjust their intentions (Heiland et al. 2005; Iacovou and Tavares 2010). When they realise they cannot meet their goals, i.e. having the number of children they had intended before their biological deadline, they adjust their intentions in order to reduce disappointment when failing to carry out their plans (Heckhausen 1999, cited in Liefbroer 2009). Other factors may be decreased fecundity caused by postponement of childbearing to higher ages and, as we could show, an unfavourable partnership situation.

\section{Table 3}

Total intended number of children, means

\begin{tabular}{|l|c|c|c|c|c|}
\hline & $25-29$ & $30-34$ & $35-39$ & $40-45$ & Total \\
\hline Scientists & 1.9 & 1.9 & 1.4 & 1.3 & 1.7 \\
\hline Tertiary educated & 2.0 & 2.0 & 1.7 & 1.5 & 1.8 \\
\hline Secondary and lower educated & 2.0 & 2.1 & 1.9 & 1.9 & 2.0 \\
\hline
\end{tabular}

As mentioned earlier, previous studies found elevated levels of final childlessness among female scientists. In order to follow up on this our data include an explicit question on intended childlessness (Table 4). ${ }^{10}$ In the youngest age group, $25-34$ years, $11 \%$ of scientists state to want to remain rather or definitely childless, while the respective share is $8 \%$ among tertiary educated and 6\% among secondary and lower educated non-scientists. This means that initially only a small share of women did not regard children as part of their life plan in all three groups. With age, these shares increase in all three groups to $19 \%, 15 \%$ and $10 \%$ respectively.

Disaggregating by disciplines, we find that intended childlessness is slightly higher among women who studied humanities and arts than among graduates from natural sciences. In other disciplines, absolute numbers in the age group 35-45 years are too small to allow further analyses.

\footnotetext{
${ }^{10}$ The question on intended childlessness is not part of the core GGS questionnaire and was included in the Austrian GGS only. It was posed rather at the beginning of the interview, before the respondent was asked indepth questions about fertility ideals, intentions and behaviour: In how far does the following statement apply to you personally? 'I want to stay childless'. (1) Does not apply at all, (2) rather not applies, (3) rather applies, (4) definitely applies.
} 
Table 4

Voluntary childlessness (in \%)

\begin{tabular}{|c|c|c|c|c|c|c|c|}
\hline & Age & $\begin{array}{l}\text { Have } \\
\text { children }\end{array}$ & $\begin{array}{l}\text { Childless- } \\
\text { ness } \\
\text { definitely } \\
\text { not } \\
\text { wanted } \\
\end{array}$ & $\begin{array}{l}\text { Childless- } \\
\text { ness rather } \\
\text { not } \\
\text { wanted }\end{array}$ & $\begin{array}{l}\text { Childless- } \\
\text { ness rather } \\
\text { wanted }\end{array}$ & $\begin{array}{l}\text { Childless- } \\
\text { ness } \\
\text { definitely } \\
\text { wanted }\end{array}$ & Total \\
\hline \multirow{3}{*}{ Scientists } & $25-34$ & 16 & 56 & 17 & 7 & 4 & 100 \\
\hline & $35-45$ & 54 & 10 & 17 & 10 & 9 & 100 \\
\hline & Total & 29 & 40 & 17 & 8 & 6 & 100 \\
\hline \multirow{3}{*}{ Tertiary educated } & $25-34$ & 26 & 53 & 13 & 7 & 1 & 100 \\
\hline & $35-45$ & 64 & 8 & 12 & 8 & 7 & 100 \\
\hline & Total & 45 & 31 & 12 & 8 & 4 & 100 \\
\hline \multirow{3}{*}{$\begin{array}{l}\text { Secondary and } \\
\text { lower educated }\end{array}$} & $25-34$ & 55 & 31 & 8 & 4 & 2 & 100 \\
\hline & $35-45$ & 83 & 5 & 2 & 4 & 6 & 100 \\
\hline & Total & 71 & 15 & 5 & 4 & 5 & 100 \\
\hline
\end{tabular}

Let us now turn to the actual childbearing behaviour. Female scientists' level of realised fertility appears to be in sharp contrast to their ideals and intentions. Conforming to previous studies which document an (almost) final childlessness of $45-60 \%$, we detect that $44 \%$ of female scientists in the age group 40-44 have no children. This value compares to $29 \%$ among tertiary educated and 16\% among secondary and lower educated women (Table 5). Scientists fall short by far of their ideals and intentions of 2 children reaching only 0.9 on average. What is more, also the mean number of children born to mothers lies with 1.6 below the respective averages of 1.9 for tertiary educated and 2.1 for secondary and lower educated non-scientists. Realized fertility almost skyrockets for women with no university degree from 0.6 in their late twenties to 1.8 in their early forties with the largest rate of increase in their late 20 s and early $30 \mathrm{~s}$. Both scientists and women with tertiary education forgo childbearing almost entirely before the age of 30 which corresponds to the period when they study and enter the labour market. Thereafter, non-scientists with tertiary education show signs of recuperation throughout their thirties and early forties, whereas the mean number of children increases much slower among scientists. The mean number of children increases from 0.6 (age 30-34) to 1.3 (age 40-45) for women with tertiary education and from 0.3 (age 30-34) to 0.9 (age 4045) for female scientists. 
Table 5

Number of children

\begin{tabular}{|c|c|c|c|c|c|c|c|}
\hline & \multirow[b]{2}{*}{ Age } & \multicolumn{4}{|c|}{ Number of children (in \%) } & \multirow[t]{2}{*}{ Mean } & \multirow{2}{*}{$\begin{array}{c}\text { Mean } \\
\text { (mothers only) }\end{array}$} \\
\hline & & 0 & 1 & 2 & $3+$ & & \\
\hline \multirow{5}{*}{ Scientists } & $25-29$ & 94 & 5 & 0 & 2 & 0.1 & 1.5 \\
\hline & $30-34$ & 75 & 17 & 6 & 2 & 0.3 & 1.4 \\
\hline & $35-39$ & 49 & 32 & 19 & 0 & 0.7 & 1.4 \\
\hline & $40-45$ & 44 & 28 & 22 & 6 & 0.9 & 1.6 \\
\hline & Total & 71 & 18 & 9 & 2 & 0.4 & 1.5 \\
\hline \multirow{5}{*}{ Tertiary educated } & $25-29$ & 93 & 7 & 0 & 0 & 0.1 & 1.0 \\
\hline & $30-34$ & 60 & 22 & 15 & 3 & 0.6 & 1.5 \\
\hline & $35-39$ & 48 & 21 & 26 & 5 & 0.9 & 1.7 \\
\hline & $40-45$ & 29 & 23 & 37 & 11 & 1.3 & 1.9 \\
\hline & Total & 55 & 19 & 21 & 5 & 0.8 & 1.7 \\
\hline \multirow{5}{*}{ Secondary and lower educated } & $25-29$ & 59 & 22 & 15 & 4 & 0.6 & 1.6 \\
\hline & $30-34$ & 30 & 27 & 31 & 12 & 1.3 & 1.8 \\
\hline & $35-39$ & 20 & 25 & 38 & 18 & 1.6 & 2.0 \\
\hline & $40-45$ & 16 & 23 & 40 & 21 & 1.8 & 2.1 \\
\hline & Total & 29 & 24 & 32 & 15 & 1.4 & 2.0 \\
\hline
\end{tabular}

The data suggest large differences in the timing of motherhood. To assess the transition rate to first child, we calculated Kaplan-Meier estimates, which take into account censoring at the time of the interview (Figure 1). Women with university degree postpone childbearing to their thirties and later. While the median age lies at 27 for the lowest educational category, it stands at 34 for the non-scientists and is as high as 37 for the female scientists.

\section{Figure 1}

Proportion of childless women, Kaplan-Meier survival curves

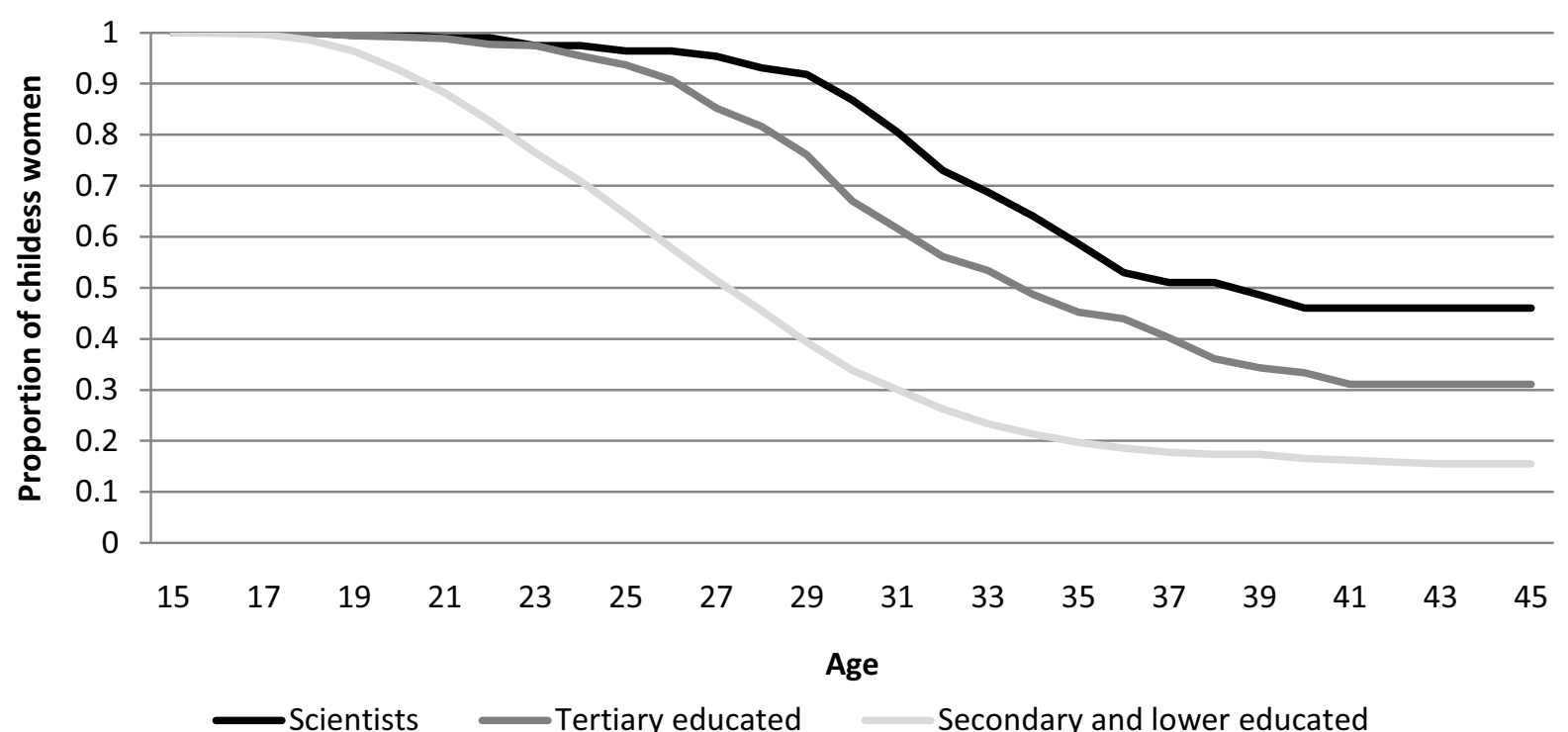


The gaps between ideals, intentions and actual behaviour are graphically depicted in Figure 2 . Again, personal ideals are rather stable across age groups and educational levels, with slightly higher ideals among lower educated women and lower ideals among scientists aged 40 years and older. The number of realized children increases with age, but whereas the difference between personal ideal and realization decreases substantially for lower educated women, we identify a persistent gap between ideals and realization among women with tertiary education, and - even more pronounced - among female scientists. For most scientists, children are initially a part of their life concept but they are only able to realize about half of the number they perceive as ideals. This holds true after they had even decreased their ideals in the oldest age group. ${ }^{11}$ The degree of realizing ideals is much higher among women with tertiary education (40-45: 62\%) and lower educated women (40-45: 78\%).

For all age groups, the personal ideal number of children is higher than the intended number of children. The ideal number of children seems to be an upper boundary which is not necessarily perceived to be compatible with the 'reality'. The difference between ideals and intentions becomes more pronounced over time as intentions decrease steeper than ideals in the second half of the thirties. Differences in personal ideals and intentions exist across all educational groups. Nevertheless, they seem to be most pronounced among scientists.

\section{Figure 2}

Personal ideal number of children, intended number of children and children born, means

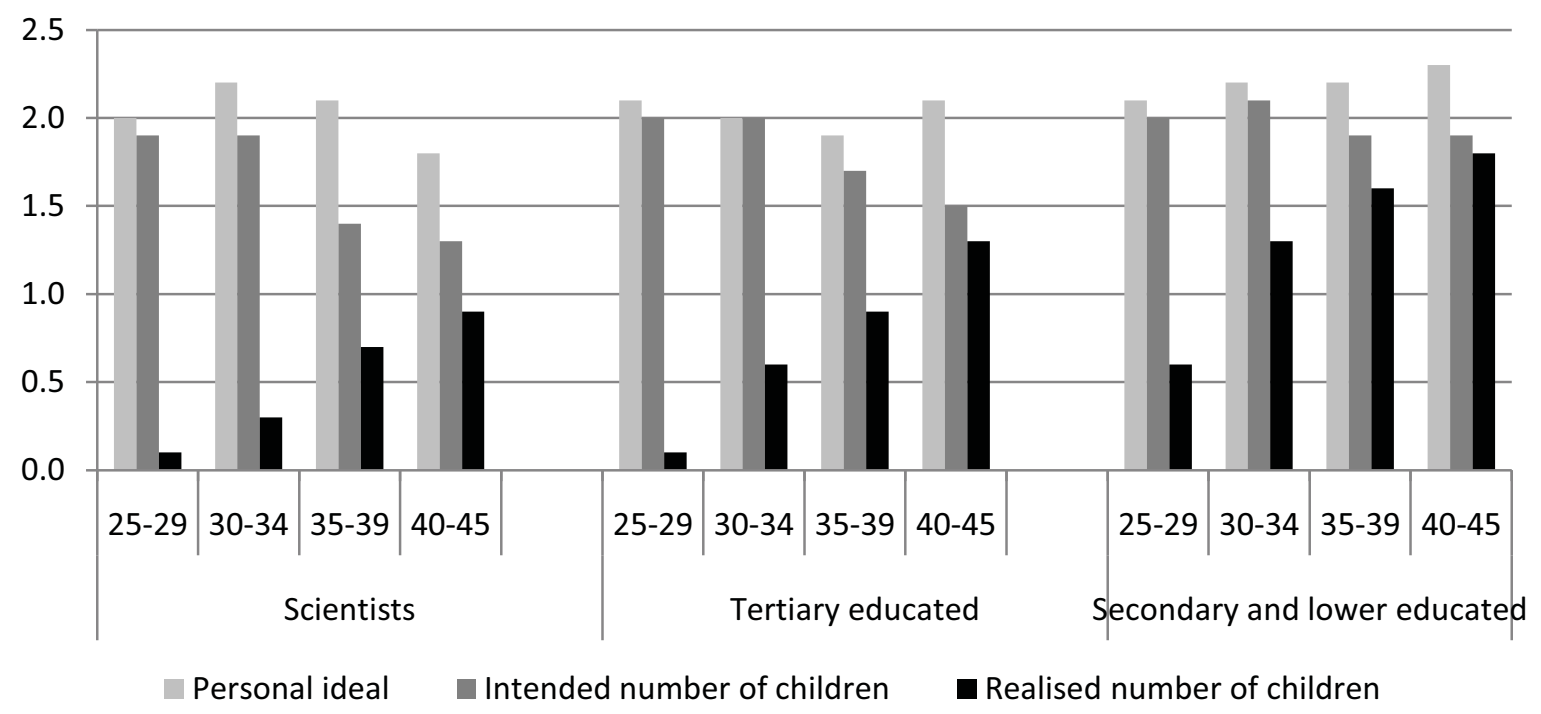

\subsection{Combining scientific work and motherhood}

Austria was classified among the conservative welfare states (e.g. Gauthier 2002). Its family policy is characterised by comparatively long parental leave entitlements, high payments and limited childcare facilities for children under the age of three years. In fact, Austria ranges among the countries with the lowest enrolment rate of children in childcare

\footnotetext{
${ }^{11}$ Relating the mean number of children born to the mean number of personal ideals we try to quantify the degree of realized ideals. Although this is a rather crude measure, it might be useful for quantifying the degree of realization. We divided the mean number of children born by the mean number of personal ideals: Scientists aged 35 to 39 years: $0.7 / 2.1=33 \%$; scientists aged 40 to 45 years: $0.9 / 1.8=50 \%$.
} 
aged under three (Plantenga and Remery 2009). This institutional context as well as limited engagement of fathers and peoples' attitudes towards gender roles and formal childcare (Wernhart and Neuwirth 2007) favour a relatively long withdrawal of mothers from the labour force after the birth of a child and the return on a part time basis.

Women's labour force participation varies strongly by number of children and age of the youngest child. Among childless women, a higher labour force participation rate is discernible with mostly full-time employment. Among mothers, differences between female scientists, women with tertiary education and women with secondary and lower education are remarkable (Figure 3). Female scientists return back to their workplaces relatively soon after the birth of a child: Fulltime employment rises from 19\% for mothers of toddlers ( $0-2$ years) to $53 \%$ for mothers of children in typical age for Kindergarten in Austria (3-5 years) to $70 \%$ among scientists whose youngest child attends elementary school (6-10 years). Since not many interviewed scientists have two or more children, the youngest child is often the only child. Fulltime employment is less common among tertiary educated women with young children ( 0 -2 years: $8 \%$; 3-5 years: $30 \%$; $6-10$ years: $40 \%)$ and even more rare among women with secondary and lower education $(0-2$ years: $5 \% ; 3-5$ years: $18 \% ; 6-10$ years: $27 \%)$.

Summing up full-time and part-time work of 20 and more hours, reveals the following picture: In total, $53 \%$ of scientists with toddlers aged $0-2$ years, $86 \%$ with children aged 3-5 years and 90\% with children attending elementary school worked 20 hours and more per week. Differences to the other two groups of women are sizeable: Differentiating by the age of the youngest child, enrolment in part-or fulltime work rises from $28 \%(0-2$ years) to $65 \%$ (3-5 years) and 79\% (6-10 years) among women with tertiary education and from $17 \%$ to $50 \%$ and $70 \%$ among women with secondary and lower education.

\section{Figure 3}

Employment by age of the youngest child

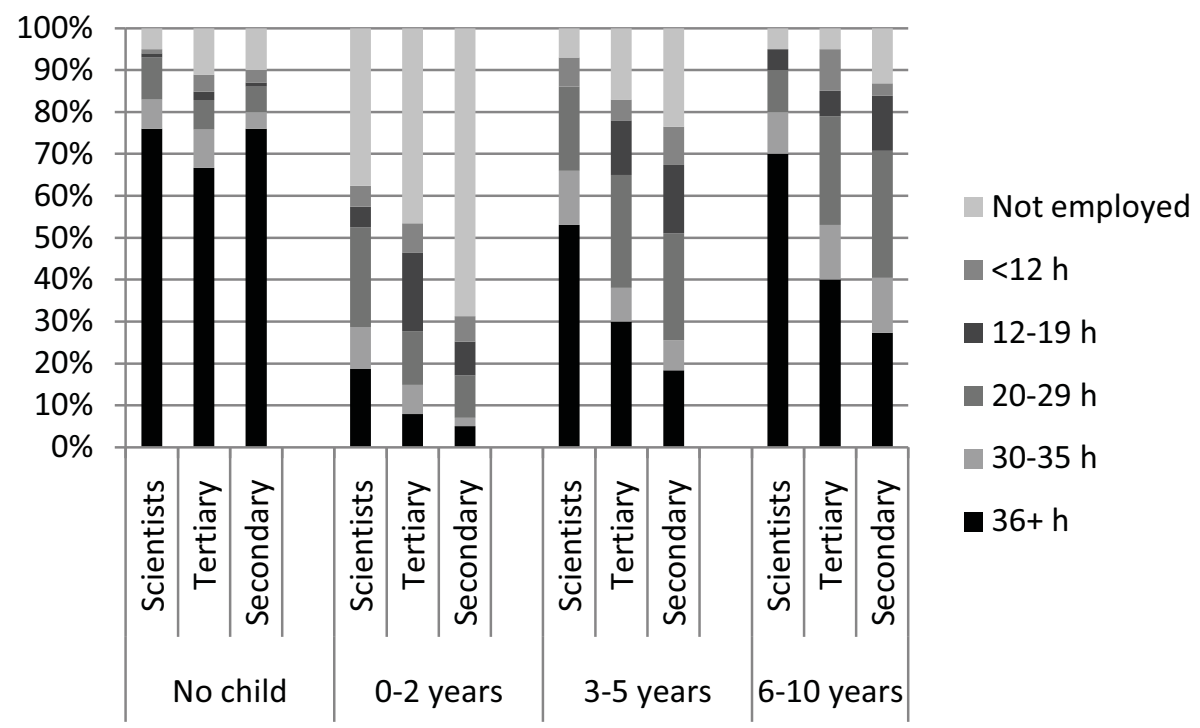

Note: Table includes childless women and women whose youngest child is not older than 10 years.

Besides the distribution of different working arrangements, the mean number of working hours is a further measure which clearly reflects the high work engagement of scientists with children (Table 6). Next to unpaid work for household and childrearing, mothers with toddlers 
under the age of two work on average 19 hours a week in paid work, mothers of children between three and five work on average on an extended part-time contract (35.1 hours) and mothers of children in primary school age work on average 38.4 hours per week. Comparing with other educational groups, the differences are most striking for mothers of toddlers (scientists: 19.0 hours; tertiary educated: 12.3 hours; secondary and lower educated: 6.9 hours) and mothers with children in typical age for Kindergarten (scientists: 35.1 hours; tertiary educated: 25.2 hours; secondary and lower educated: 19.2 hours). With increasing age of the child, labor force participation increases substantially also for tertiary educated (28.7 hours) and secondary and lower educated (25.7). But whereas tertiary and secondary and lower educated tend to combine childrearing and household with part-time employment, many scientists return back to full-time employment soon after the birth of a child.

Table 6

Mean working hours by age of youngest child

\begin{tabular}{|l|c|c|c|c|c|}
\hline & No child & $0-2$ years & $3-5$ years & $6-10$ years & Total \\
\hline Scientists & 40.2 & 19.0 & 35.1 & 38.4 & 37.2 \\
\hline Tertiary educated & 35.0 & 12.3 & 25.2 & 28.7 & 29.7 \\
\hline Secondary and lower educated & 34.3 & 6.9 & 19.2 & 25.7 & 24.2 \\
\hline
\end{tabular}

Note: The numbers refer to the actual working hours per week. The table includes childless women and women whose youngest child is not older than 10 years.

Our results have to be interpreted with certain caveats. First, our sample is selected insofar as unemployed female scientists are obviously underrepresented. Second, due to the small number of respondents, single outliers might distort our results. Variance in our small sample is high, confidence intervals are wide and often overlap with those of our two comparison groups. Third, whereas mothers among our interviewed scientists have mostly one child, women with tertiary and secondary and lower education have more often two or more children, which has an additional effect on the female labour force participation. Taking these caveats into account, our descriptive results can only reveal trends and tendencies. Numbers should be regarded with caution.

Who cares or should care for children when their mothers work? Our analyses reveal striking differences with regard to fathers taking parental leave: $31 \%$ of mothers working as scientists report that their partners took parental leave, which was less often the case among tertiary educated $(14 \%)$ or lower educated mothers $(6 \%)$. Although, again, the numbers have to be regarded with caution, our results indicate a remarkable support by the partners of female scientists regarding parental leave arrangements. 


\section{Figure 4}

Duty to care for children under the age of three

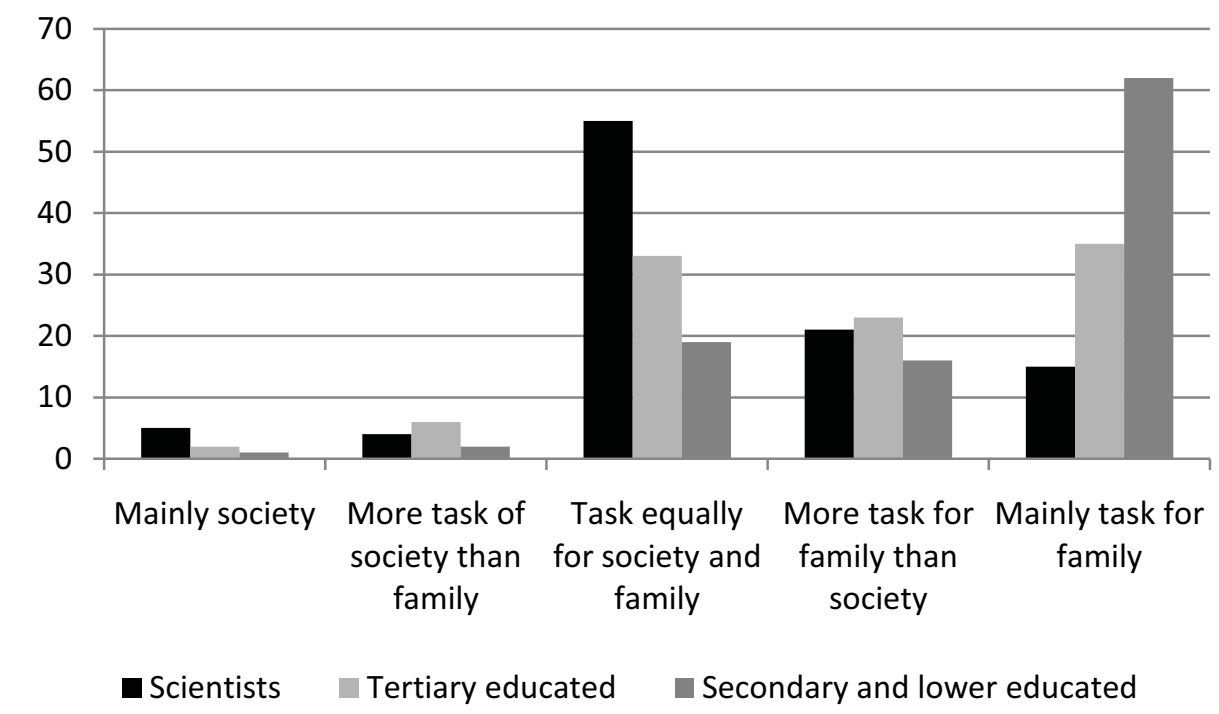

Attitudes on institutional childcare vary widely across different societal groups. Figure 4 presents the responses to the question whether it should be mainly the task of society, the family or both to care for children under the age of three. The majority of scientists $(55 \%)$ is convinced that this task should be equally shared by society and family whereas secondary and lower educated tend to ascribe this duty to the family $(62 \%)$. Tertiary educated women have an intermediate attitude and lie between these two opposing positions. Regardless of the educational level, only few women prefer the society to act as the main care giver of very small children. While it is common practice in other European countries, like France, Denmark or Belgium, to have small children in crèches, only highly educated Austrian women regard this practice as a suitable arrangement for rearing children under the age of three. Although scientists assign a certain responsibility for early childrearing towards the society and the state, the necessity and importance of the nuclear family is equally approved.

Regarding the same question pertaining to children aged three to six, at least half of respondents in each group believe that the task of caring should be equally shared between society and family. Scientists and tertiary educated women tend towards a higher involvement of the state, secondary and lower educated women prefer a higher involvement of the family (Figure 5). When it comes to caring for schoolchildren in the afternoon (i.e. during afterschool hours), the trend towards approving higher engagement of the society among highly educated women continues. Generally speaking, the older the child the more often scientists and tertiary educated women opt for an engagement of the society. Presumably, higher educated women more often use or intend to use childcare facilities in order to combine family and employment, and therefore know better about the possibilities and possible advantages of private or public childcare facilities and have less doubts concerning extrafamilial childcare. 


\section{Figure 5}

Duty to care for pre-school children aged three and above

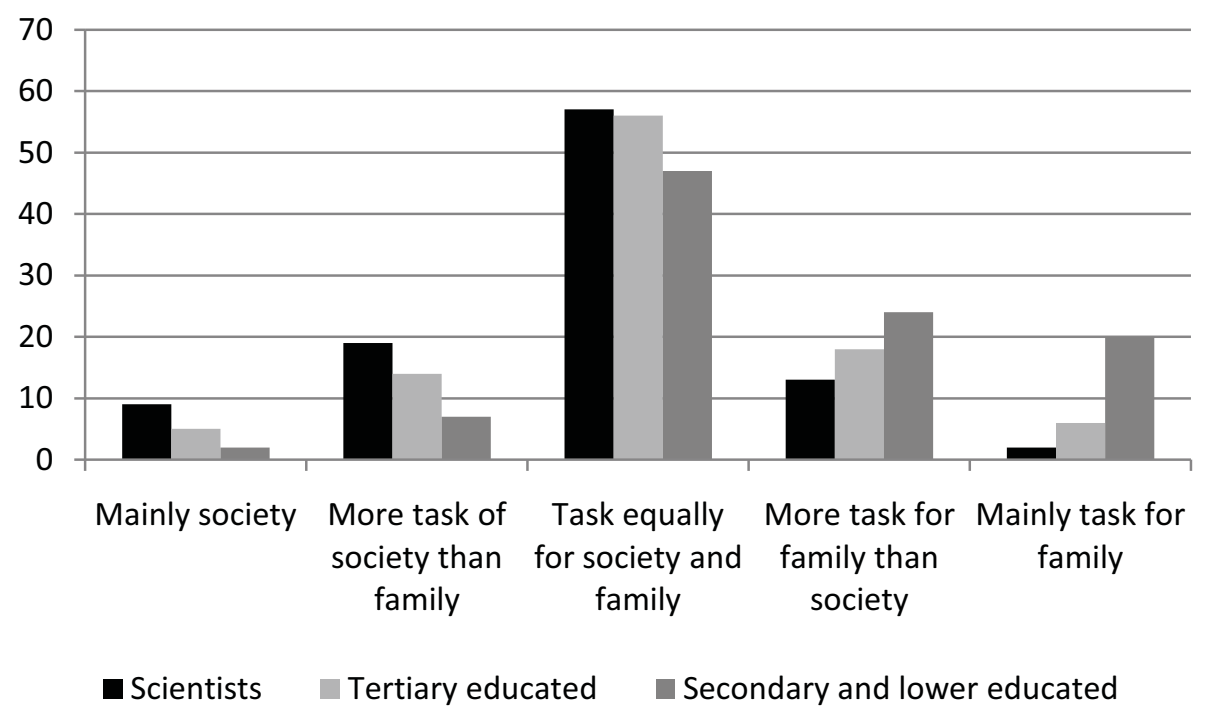

The interviewed scientists and highly educated women mainly live in the urban regions where they attained their higher education and where the job market is more favourable for them. In our data, the geographical distance to the parents or the closest parent is larger among highly educated women - especially scientists - than among lower educated women. For part of them this might mean that they can less often rely on daily or regular help of their parents with regard to childrearing. They are therefore more often dependent on private or public childcare facilities, because they less often have familial networks available. In rural areas, on the other hand, parents can more often dispose of grandparents' help with childrearing. Moreover, in Austria the availability of childcare facilities - especially for children under the age of three - varies markedly between urban and rural areas and is rather scarce in rural areas or small cities. These factors may partly explain why highly educated women tend towards an engagement of the society in caring for children.

But additionally, different attitudes about the role of a woman, relative satisfaction from work and family and perceived effects of external childcare on the wellbeing of children play a role. Scientists more often strongly disagree that looking after the household and caring for children is as fulfilling as working for pay and less often (strongly) agree than their peers. But many of them also choose the neutral central category. About half of secondary and lower educated women (strongly) agree that being a housewife and mother is as fulfilling as working in a paid job. Tertiary educated non-scientists take a middle position between the two other groups.

Differences in attitudes are even more pronounced when asked whether a preschool child suffers if his or her mother works. Scientists clearly object to this question, close to $80 \%$ (strongly) disagree to negative consequences for children. Such disapproval is much lower among tertiary educated women (53\%) and especially among secondary and lower educated women $(40 \%)$ - they are particularly cautious to declare that they strongly disagree. 


\section{Discussion}

Low fertility among women of higher educational level in Austria indicates that either the intentions to have children are low or alternatively that there exists a gap between childbearing intentions and their realization. In this paper we want to clarify which of both arguments may apply to explain the negative educational gradient of fertility in Austria and to shed some light on incompatibilities of childrearing and working life that may explain low fertility levels.

More specifically, since fertility differentials are pronounced across occupations within higher educational levels we specifically focus on the group of females who work in science and compare them to tertiary educated non-scientists. Female scientists constitute an interesting case study to investigate in various aspects. Firstly, women are still underrepresented in science - particularly at higher occupational levels. Secondly, the scientific profession is characterized by high geographic mobility, temporary contracts, continuous investment in human capital, networking, long working hours, etc. - characteristics that may all be detrimental to combine family and childrearing.

While a number of previous studies have demonstrated that female scientists have very low numbers of children and elevated childlessness levels (Buchholz 2004 and Fieder et al. 2005 for Austria), they did not address the role of fertility intentions in this context.

Our sample is based on a rather small number of female scientists implying that the differences between female scientists and women with tertiary or secondary and lower education are mostly not statistically significant. Despite this drawback our descriptive analysis may offer insights into potential factors that shape female scientists' fertility and childrearing behaviour.

We have structured our results by first considering the living conditions of female scientists including their educational level, employment and partnership status. Compared to women with tertiary or lower educational level, female scientists exhibit higher shares of full time employment. Almost three quarters of female scientists have only a temporary contract which may imply considerable uncertainty for long term irreversible decisions such as family formation and in particular child bearing and rearing. In terms of partnership status, female scientists are more likely to cohabit or live - often involuntarily - apart together.

Fertility ideals and intentions across different educational groups are similar up to the age of 34 years. However in the age groups 35-39 and 40-45 intentions decrease substantially for women with tertiary education and even more for female scientists. Among female scientists about $44 \%$ stay childless while these shares reduce to $29 \%$ for tertiary educated and $16 \%$ for secondary and lower educated women. Our data indicate that females with tertiary education (including scientists as well as non-scientists) postpone childbearing past age 30 with lower levels of recuperation of fertility for scientists.

Considering the compatibility of work and motherhood we find that female scientists return to work relatively soon after the birth of a child and have higher mean numbers of working hours as compared to non-scientists and females of lower educational level. We also find a higher involvement of partners in childcare with regard to female scientists. Being asked about their attitudes towards institutional childcare, female scientists clearly argue for the role 
of the state while females of lower educational level are rather suggesting a division of state and private provisions.

Summing up our descriptive analysis we may conclude that the low fertility of female scientists is explained by the gap between fertility intentions and behavior rather than lower levels of fertility intentions (although we found some adjustment of intentions over the life cycle). Prior studies show that fertility intentions do not differ greatly by educational level (for Austria Sobotka 2009), whereas the levels of realization vary. Our results are in line with these findings but we extend them to the group of female scientists. This gap between intentions and realizations may be explained by conditions directly related to the working place (e.g. temporary working contracts) and possibly also to less favorable partnership relations (e.g. living apart together). However, as the data also indicate, female scientists who have children show a high attachment to the labor market, event shortly after the birth of a child.

Although it is difficult to deduce clear cut policy implications from our descriptive findings, we may nevertheless hint towards opportunities to allow female scientists to also realize their intended fertility levels. Firstly, offering longer term contracts may be an important argument to increase job security and therefore allow for long term planning such as having children. Secondly, institutional childcare should increase in line with views of our interviewed female scientists that the state should resume some part of childcare responsibility. Thirdly, a common practice at many universities in the US is to also offer positions for partners. In light of the high share of female scientists that indicated to live apart from their partner, this may constitute an important step towards easing the combination of work and family life. 


\section{References}

Ackers, L. \& Gill, B. 2008, Moving people and knowledge. Scientific mobility in an enlarging European Union, Elgar Publishing, Cheltenham.

Allmendinger, J., von Stebut, J., Fuchs, S. \& Brückner, H. 1999, 'Eine Liga für sich? Berufliche Werdegänge von Wissenschaftlerinnen in der Max-Planck-Gesellschaft' in Vielfältige Verschiedenheiten. Geschlechterverhältnisse in Studium, Hochschule und Beruf, eds. A. Neusel \& A. Wetterer, Campus, Frankfurt/Main, pp. 193-220.

Appelt, E. (ed.) 2004, Karrierenschere. Geschlechterverhältnisse im österreichischen Wissenschaftsbetrieb, LIT, Vienna.

Armenti, C. 2004, 'Women faculty seeking tenure and parenthood: Lessons from previous generations', Cambridge Journal of Education, vol. 34, no. 1, pp. 65-83.

Auferkorte-Michaelis, N., Metz-Göckel, S., Wergen, J. \& Klein, A. 2006, 'Junge Elternschaft und Wissenschaftskarriere. Wie kinderfreundlich sind Wissenschaft und Universitäten?' Universität Dortmund, Hochschuldidaktisches Zentrum, Available from: $<$ http://zeus.zeit.de/online/2006/15/studie dortmund.pdf $>$ [ 9 July 2010].

Beaufaÿs, S. 2006, 'Von Goldgräbern und Körperlosen. Mythos und Alltag wissenschaftlicher Lebensführung' in: Work-life balance \& Wissenschaft - ein Widerspruch?, eds M. Buchmayr \& J. Neissl, LIT, Vienna, pp. 11-21.

Becker, G. 1993, Human capital. A theoretical and empirical analysis with special reference to education, University of Chicago Press, Chicago.

BMWF 2010, Online database uni: data. Available from: $<$ http://eportal.bmbwk.gv.at/discoverer/viewer?\&cn=cf a104\&nlsl=deat\&fm=p://eportal.bmbwk.gv.at/discoverer/viewer?\&_po=10000000001100111011000\& $\underline{w b r}=896993 \& w b k=E L E M E N T 2102>$ [9 July 2010].

Buber, I. 2010a, 'Wissenschaftlerinnen in Österreich - Zusatzerhebung im Rahmen des GGS. Dokumentation der Datenerhebung und deskriptive Ergebnisse', VID Working Paper 2/2010, Vienna: Vienna Institute of Demography of the Austrian Academy of Sciences.

Buber, I. 2010b, 'Parity-specific weights for the Austrian Generations and Gender Survey', VID Working Paper 4/2010, Vienna: Vienna Institute of Demography of the Austrian Academy of Sciences.

Buchholz, L. 2004, 'Wissenschaftskarrieren an österreichischen Universitäten. Erfahrungen und Einstellungen von Professorinnen und Professoren' in: Karrierenschere. Geschlechterverhältnisse im österreichischen Wissenschaftsbetrieb, ed E. Appelt, LIT Verlag. Vienna, pp. 71-91.

Buchinger, B. 2006, 'Skizzen zur "work-life-balance" bei WissenschaftlerInnen an österreichischen Universitäten' in: Work-life balance \& Wissenschaft - ein Widerspruch?, eds M. Buchmays \& J. Neissl, LIT, Vienna, pp. 23-38.

Buchinger, B., Gödl, D. \& Gschwandtner, U. 2002, Berufskarrieren von Frauen und Männern an Österreichs Universitäten. Eine sozialwissenschaftliche Studie über die Vereinbarkeit von Beruf und Privatem, Materialien zur Förderung von Frauen in der Wissenschaft, Bd. 14, Verlag Österreich, Vienna.

Buchinger, B., Gödl, D. \& Gschwandtner, U. 2004, 'Karriereverläufe und Vereinbarkeit von Beruf und Privatem bei WissenschaftlerInnen' in: Karrierenschere.

Geschlechterverhältnisse im österreichischen Wissenschaftsbetrieb, ed E. Appelt, LIT, Vienna, pp. 47-69.

Buchmayr, M. \& Neissl. J. (eds.) 2006, Work-life balance \& Wissenschaft - ein Widerspruch? LIT, Vienna. 
Comer, D.R. \& Stites-Doe, S. 2006, 'Antecedents and consequences of faculty women's academic-parental role balancing', Journal of Family and Economic Issues, vol. 27, pp. 495-512.

Dorbritz, J. 2008, 'Germany: Family diversity with low actual and desired fertility', Demographic Research, vol. 19, no. 17, pp. 557-598.

EC 2009, She figures 2009. Statistics and indicators on gender equality in science. Available from: http://ec.europa.eu/research/sciencesociety/document library/pdf_06/she figures_2009 en.pdf [9 July 2010].

Fieder, M., Huber, S., Bookstein, F.L., Iber, K., Schäfer, K., Winckler, G. \& Wallner, B. 2005, 'Status and reproduction in humans: New evidence for the validity of evolutionary explanations on basis of a University sample', Ethology, no. 111, pp. 940-950.

Fox, M.F. 2005, 'Gender, family characteristics and publication productivity among scientists', Social Studies of Science, vol. 35, no.1, pp. 131-150.

Fox, M.F. \& Faver, C.A. 1985, 'Men, women and publication productivity: Patterns among social work academics', Sociological Quarterly, vol. 26, no.4, pp. 537-549.

Frejka, T. 2008, 'Parity distribution and completed family size in Europe: Incipient decline of the two-child family model', Demographic Research, vol. 19, no. 4, pp. 47-72.

Gauthier, A. 2002, 'Family policies in industrialized countries: Is there convergence? ', Population, vol. 57, no. 3, pp. 447-474.

Greenhaus, J.H. \& Beutell, N.J. 1985, 'Sources of conflict between work and family roles', The Academy of Management Review, vol. 10, no. 1, pp. 76-88.

Hakim, C. 2003, 'A new approach to explaining fertility patterns: Preference theory', Population and Development Review, vol. 29, no. 3, pp. 349-374.

Hamovitch, W. \& Morgenstern, R.D. 1977, 'Children and the productivity of academic women', Journal of Higher Education, vol. 48, no. 6, pp. 633-645.

Hargens, L.L., McCann, J.C. \& Reskin, B.F. 1978, 'Productivity and reproductivity: Fertility and professional achievement among research scientists', Social Forces, vol. 57, no. 1, pp. 154-163.

Haslinger, A. 1982, 'Uneheliche Geburten in Österreich. Historische und regionale Muster' in: Demographische Informationen 1982, ed Institut für Demographie, Verlag der Österreichischen Akademie der Wissenschaften, Vienna, pp. 2-34.

Heckhausen, J. 1999, Developmental regulation in adulthood. Age-normative and sociostructural constraints as adaptive challenges, Cambridge University Press, Cambridge.

Heiland, F., Prskawetz, A. \& Sanderson, W.C. 2005, 'Do the more-educated prefer smaller families?', Vienna Institute of Demography Working Paper 3/05, Vienna: Vienna Institute of Demography of the Austrian Academy of Sciences.

Iacovou, M. \& Tavares, L.P. 2010, 'Yearning, Learning and Conceding: (Some of) the Reasons People Change their Childbearing Intentions', European Demographic Research Papers 3. Vienna: Vienna Institute of Demography of the Austrian Academy of Sciences.

Ingrisch, D. 1993, “Alles war das Institut!” Eine lebensgeschichtliche Untersuchung über die erste Generation von Professorinnen an der Universität Wien. Materialien zur Förderung von Frauen in der Wissenschaft, Bd. 2, Vienna.

Kemkes-Grottenthaler, A. 2003, 'Postponing or rejecting parenthood? Results of a survey among female academic professionals', Journal of Biosocial Science, vol. 35, pp. 213-226.

Kreetz, T. 2004, 'Wissenschaftlerinnen in der außeruniversitären Forschung: Deutschland, Frankreich und Österreich im Vergleich' in: Karrierenschere. Geschlechterverhältnisse im österreichischen Wissenschaftsbetrieb, ed E. Appelt, LIT, Vienna, pp. 161-179. 
Krimmer, H., Stallmann, F., Behr, M. \& Zimmer, A. (n. d.). Karrierewege von ProfesorInnen an Hochschulen in Deutschland. Available from: $<$ http://www.mentoring.uzh.ch/literatur/wika broschuere.pdf $>$ [9 July 2010].

Kyvik, S. 1990, 'Motherhood and scientific productivity', Social Studies of Science, vol. 20, no. 1 , pp. 149-160.

Leemann, R.J. 2002, Chancenungleichheiten im Wissenschaftssystem: wie Geschlecht und soziale Herkunft Karrieren beeinflussen, Rüegger, Zurich.

Liefbroer, A. 2009, 'Changes in family size intentions across young adulthood: a life-course perspective', European Journal of Population, vol. 25, no. 4, pp. 363-386.

Lind, I. 2007, 'Ursachen der Unterrepräsentanz von Wissenschaftlerinnen - Individuelle Entscheidungen oder strukturelle Barrieren? ' in: Exzellenz in Wissenschaft und Forschung. Neue Wege in der Gleichstellungspolitik. Dokumentation der Tagung am 28./29. 11. 2006 in Köln, ed Wissenschaftsrat, pp. 59-86. Available from: $<$ http://www.wissenschaftsrat.de/download/archiv/ChancGleichDoku.pdf $>$ [ 9 July 2010].

Lind, I. 2008, 'Dossier Balancierung von Wissenschaft und Elternschaft. Auswahl erster Ergebnisse der Online-Befragung', Kompetenzzentrum Frauen in Wissenschaft und Forschung / GESIS. Available from: $<$ http://www.bawie.de/web/files/49/de/Ergebnisbericht.pdf $>$ [9 July 2010].

Lind, I. \& Banavas, T. (n.d.). Balancierung von Hochschulkarriere und Elternschaft - Ein Überblick. Available from: $<$ http://www.bawie.de/web/files/15/de/Artikel DHB final.pdf $>$ [9 July 2010]

Litwin, H. \& Sapir, E.V. 2009, 'Perceived income adequacy among older adults in 12 countries: Findings from the Survey of Health, Ageing, and Retirement in Europe', The Gerontologist, vol. 49, no. 3, pp. 397-406.

Long, S.J. \& Fox. M.F. 1995, 'Scientific careers: Universalism and particularism', Annual Review of Sociology, vol. 21, pp. 45-71.

Macha, H. 2005, 'Mütter als Wissenschaftlerinnen: Forschungsstand und politische Maßnahmen der Frauenförderung - ein Einführung' in: Karriere und Kind. Erfahrungsberichte von Wissenschaftlerinnen, eds N. Biller-Andorno, A.-K. Jkovljević, K. Landfester \& M.A. Lee-Kirsch, Campus, Frankfurt/Main.

Mathews, P. \& Sear, R. 2010, 'Context effects and fertility preferences: the influence of preceding questions on the reporting of attitudes towards fertility', Poster presented at the 2010 Annual Conference of the British Society for Population Studies BSPS, Exeter, 1315 September 2010.

McDowell, J.M. 1982, 'Obsolescence of knowledge and career publication profiles: some evidence of differences among fields in costs of interrupted careers', American Economic Review, vol. 72, no. 4, pp. 752-768.

Metz-Göckel, S. 2009, 'Wissenschaftlicher Nachwuchs ohne Nachwuchs? Zwischenergebnisse des Projekts "Wissen- oder Elternschaft? Kinderlosigkeit und Beschäftigungsverhältnisse an Hochschulen in Deutschland.' Technische Universität Dortmund, Hochschuldidaktisches Zentrum. Available from: $<$ http://www.hdz.unidortmund.de/fileadmin/Projekte/Wissen_Elternschaft/Zwischenergebnisse_WoE.pdf $>$ [9 July 2010].

Mitterauer, M. 1985, Ledige Mütter, Beck, München.

Neyer, G.R. 2009, 'Bildung und Kinderlosigkeit in Österreich und in Schweden', Zeitschrift für Familienforschung, vol. 21, no.3, pp. 287-310.

Neyer, G.R. \& Hoem, J.M. 2008, 'Education and permanent childlessness: Austria vs. Sweden. A research note' in: Demographic challenges for the $21^{\text {st }}$ century. A state of the 
art in demography, eds J. Surkyn, P. Deboosere \& J.van Bavel, Brussels University Press, Brussels, pp. 91-112.

O'Laughlin, E.M. \& Bischoff, L.G. 2005, 'Balancing parenthood and academia: Work/family stress as influenced by gender and tenure status', Journal of Family Issues, vol. 26, no. 1, pp. 79-106.

Plantenga, J. \& Remery, C. 2009, 'The provision of childcare services. A comparative review of 30 European countries', European Commission. Available under:

$<$ http://ec.europa.eu/social/main.jsp?langId=en\&catId=89\&newsId=545\&furtherNews=ye $\underline{\mathrm{s}}>$ [9 July 2010].

Prskawetz, A., Sobotka, T., Buber, I., Engelhardt, H. \& Gisser, R. 2008, 'Austria: Persistent low fertility since the mid-1980s', Demographic Research vol. 19, no. 12, pp. 293-360.

Quesnel-Vallée, A. \& Morgan, S.P. 2003, 'Missing the target? Correspondence of fertility intentions and behavior in the U.S.', Population Research and Policy Review, vol. 22, pp. 497-525.

Reuter, J., Vedder, G. \& Liebig, B. (eds.) 2008, Professor mit Kind. Erfahrungsberichte von Wissenschaftlern, Campus, Frankfurt/New York.

Romanin, S. \& Over, R. 1993, 'Australian academics: Career patterns, work roles and family life-cycle commitments of men and women', Higher Education, vol. 26, pp. 411-429.

Sobotka, T. 2009, 'Sub-replacement fertility intentions in Austria', European Journal of Population, vol. 25, pp. 387-412.

Spielauer, M. 2005, 'Concentration of reproduction in Austria: General trends and differentials by educational attainment and urban-rural setting',Vienna Yearbook of Population Research 2005, pp. 171-195.

Stack, S. 2004, 'Gender, children and research productivity', Research in Higher Education, vol. 45 , no. 8 , pp. 891-920.

Statistik Austria 2010a, [online], Available from: $<$ http://www.statistik.at/web de/statistiken/arbeitsmarkt/erwerbstaetige/index.html $>[10$ July 2010].

Statistik Austria 2010b, [online], Available from: $<$ http://www.statistik.at/web_de/statistiken/bevoelkerung/demographische masszahlen/de mographische indikatoren/index.html > [9 July 2010]

Statistisches Bundesamt 2009, Mikrozensus 2008. Neue Daten zur Kinderlosigkeit in Deutschland. Ergänzende Tabellen zur Pressekonferenz am 29. Juli 2009 in Berlin. Wiesbaden.

van Anders, S.M. 2004, 'Why the academic pipeline leaks: Fewer men than women perceive barriers to becoming professors', Sex Roles, vol. 51, no. 9/10, pp. 511-521.

Ward, K. \& Wolf-Wendel, L. 2004, 'Academic motherhood: Managing complex roles in research universities', Review of Higher Education, vol. 27, no. 2, pp. 233-257.

Wasserman, E.R. 2002, The door in the dream: conversations with eminent women in science, Joseph Henry Press, Washington.

Wernhart, G. \& Neuwirth, N. 2007, 'Geschlechterrollenwandel und Familienwerte (19882002). Österreich im europäischen Vergleich. Ergebnisse auf Basis des ISSP 1998, 2002', ÖIF Working Paper 54.

Wolfinger, N.H., Mason, M.A. \& Goulden, M. 2008, 'Problems in the pipeline: Gender, marriage and fertility in the Ivory Tower', Journal of Higher Education, vol. 79, no. 4, pp. 388-405.

Wolf-Wendel, L. \& Ward, K. 2006, 'Academic life and motherhood: Variations by institutional type', Higher Education, vol. 52, pp. 487-521. 
Wyer, M., Schneider, J., Nassar-McMillan, S., Oliver-Hoyo, M. 2010, 'Capturing stereotypes: developing a scale to explore U.S. college students' images of science and scientists', International Journal of Gender, Science and Technology, vol. 2, no. 3, pp. 382-415. 


\section{VIENNA INSTITUTE OF DEMOGRAPHY}

\section{Working Papers}

Strulik, Holger, Klaus Prettner, and Alexia Prskawetz, R\&D-Based Growth in the Post-Modern Era, VID Working Paper 09/2010.

Prettner, Klaus and Alexia Prskawetz, Demographic Change in Models of Endogenous Economic Growth. A Survey, VID Working Paper 08/2010.

Flandorfer, Priska, Christian Wegner, and Isabella Buber, Gender Roles and Smoking Behaviour, VID Working Paper 07/2010.

Barakat, Bilal, Johannes Holler, Klaus Prettner, and Julia Schuster, The Impact of the Economic Crisis on Labour and Education in Europe, VID Working Paper 06/2010.

Grafeneder-Weissteiner, Theresa and Klaus Prettner, Agglomeration Processes in Ageing Societies, VID Working Paper 05/2010.

Buber, Isabella, Parity-specific weights for the Austrian Generations and Gender Survey, VID Working Paper 04/2010.

Testa, Maria Rita, She wants, he wants: Couple's childbearing desires in Austria, VID Working Paper 03/2010.

Buber, Isabella, Wissenschaftlerinnen in Österreich - Zusatzerhebung im Rahmen des GGS.Dokumentation der Datenerhebung und deskriptive Ergebnisse, VID Working Paper 02/2010.

Kuhn, Michael, Stefan Wrzaczek, Alexia Prskawetz, and Gustav Feichtinger, Externalities in a Life-Cycle Model with Endogenous Survival, VID Working Paper $01 / 2010$.

Prettner, Klaus, Population Ageing and Endogenous Economic Growth, VID Working Paper 08/2009.

Št’astná, Anna and Tomáš Sobotka, Changing Parental Leave and Shifts in Second and Third-Birth Rates in Austria, VID Working Paper 07/2009.

Prettner, Klaus and Alexia Prskawetz, Decreasing Fertility, Economic Growth and the Intergenerational Wage Gap, VID Working Paper 06/2009.

Wegner, Christian and Marc Luy, Determinants of General Health and Specific Diseases of Elderly Women and Men: A Longitudinal Analysis for Western and Eastern Germany, VID Working Paper 05/2009.

The Vienna Institute of Demography Working Paper Series receives only limited review. Views or opinions expressed herein are entirely those of the authors. 